\title{
Characteristics of Leather and Hair Covering of Nenets Deer
}

\author{
Bakharev Aleksey Aleksandrovich \\ FSBEI HE Northern Trans-Ural SAU \\ Tyumen, Russia \\ SRIA for NTUR - Branch of Tyumen Scientific \\ Centre SB RAS \\ Moskowskiy, Tyumen region, Russia \\ e-mail salers@mail.ru \\ Aleksandrova Svetlana Sergeevna \\ SRIA for NTUR - Branch of Tyumen Scientific \\ Centre SB RAS \\ Moskowskiy, Tyumen region, Russia \\ e-mail aleksandrova977@mail.ru
}

\author{
Sheveleva Olga Mikhailovna \\ FSBEI HE Northern Trans-Ural SAU \\ Tyumen, Russia \\ e-mail olgasheveleva72@mail.ru
}

\author{
Renev Evgeny Petrovich \\ SRIA for NTUR - Branch of Tyumen Scientific \\ Centre SB RAS \\ Moskowskiy, Tyumen region, Russia \\ -mail aleksandrova977@mail.ru
}

\author{
Koshchaev Andrey Georgievich \\ Kuban State Agrarian University \\ Krasnodar, Russia \\ e-mailkagbio@mail.ru
}

\begin{abstract}
The paper presents the characteristics of leather and hair of Nenets deer of different age and sex groups. The results obtained in the course of study indicate that the hair covering is much better in young animals. With age, there is a gradual decrease in the hair thickness and a slight increase in its length. The number of hairs of females per $1 \mathrm{~cm} 2$ of skin prevails over males, but the top hair of males is visually thicker and the structure has more down hair. The color characteristics of deer have shown that dark-brown and brown colors predominate in Nenets deer bred in OOO State Farm Baydaratsky, ZAO Nydinskoe, and Municipal Deer Farm Yarsalinskoe, which accounts for more than half of the total livestock.
\end{abstract}

Keywords - deer, Nenets deer, hair, hair structure, color.

\section{INTRODUCTION}

As $1 / 16$ of the territory of Russia is located in tundra, the reindeer herding plays an important role for national economy. It is the main occupation, and, moreover, the way of life of the majority of small-numbered peoples of the North. Being not costly, the reindeer herding provides a lot of valuable products, and, therefore, it is the most cost-effective industry.

Deer may contribute a lot to the development of vast territories of the region in terms of agriculture, since only these animals eat lichens -- the most common plants in the North. Such sectors as animal farming, hunting, handicraft, and pharmaceutical industry are closely related to the reindeer herding, where deer is an important source of endocrine and other crude drugs [1-4].
The reindeer herding is one of the oldest branches of agriculture. The economic importance of reindeer herding for the Far North is determined by small amount of feed supplies of tundra and forest-tundra consumed by deer and the creation of material values necessary for small-numbered peoples of the North.

For many years, the main task of the region regarding the reindeer herding, including the Tyumen North, was to provide the region's population with cheap meat, which is an indispensable product in their diet, and only in recent years a great importance has been placed on technical wastes, such as blood, antlers, horns, hooves, endocrine organs -- the most important raw materials for medical industry [5-9].

Hair covering is one of the signs of adaptability of a living organism to environmental conditions. It plays the role of a heat insulator and varies within the same species not only depending on the climatic zone, but also on the season of the year $[10,11]$.

Reindeer have a good hair covering; even the inner side of the ears, the nose mirror, the udder and the face end are covered with hair. The mane (dewlap) is well developed on the underside of the neck. In addition, the insulating properties of skin are improved due to the reduction and contraction of skin capillaries in winter.

The hair and the coat structure of reindeer is the result of their adaptation to dwelling in harsh climate. In winter, the fur forms a thick and dense hair covering, consisting of the 
covering hair, i.e. top hair and undercoat - fur hair. The top hair is spindle-shaped, the pith of which is up to $90 \%$ of the entire hair thickness, consisting of large, hollow, keratinized cells. Having this structure, the hair covering forms a thick and dense, air-saturated layer that reliably protects the body from cold in winter [12, 13].

The studies were carried out within the framework of complex biotechnological characteristics of Nenets deer in different climatic zones. According to literary sources there are no similar studies.

The purpose of study. To study hair peculiarities of Nenets deer of different age and sex groups of animals in the leading enterprises of the YNAO.

\section{DESCRIPTION OF THE STUDY}

The studies on the characteristics of hair covering were carried out in the autumn period in accordance with the methodical instructions provide by L.P. Prakhov and G.A. Chernov [14]. Hair samples were taken from the middle part of the last rib in September, when after spring molting new hair grows on the area of $1 \mathrm{~cm}^{2}$. Hair samples were taken with the help of a special device for collecting hair [15]. The hair density was determined by calculating the actual amount of hair in the sample. The length of 100 hairs is measured with graph paper.

Three heads were selected from each sex and age group to carry out studies in the main farms of the YNAO for Nenets deer breeding.

\section{RESEARCH RESULTS}

The skin of deer is a valuable raw material for leather and fur industry.

According to the structure, the skin consists of three layers, such as the epidermis, which is about $1 \%$ thicker than the skin; the middle layer, i.e. the skin itself which accounts for $84 \%$ and the subcutaneous tissue amounting to $15 \%$ [17].

The technological qualities of reindeer skin depend on multiple factors: the animal's sex, its condition, and also the time of slaughter.

During the studies the quality of deer skins obtained after the slaughter of male calves at the age of 6 months has been evaluated. The adult stud bulls and steers have gone through the same procedure in every farm. A total of 162 skins were analyzed, of which 87 skins were obtained as a result of slaughter of calves and 75 skins were obtained from adult males.

Characteristics of deer skins after the slaughter are presented in Table 1.

As a result, it was found out that the length, width and weight of skins did not change significantly within the age and sex group. The skin of young stock ranged within the following parameters: the length ranged from 101.82 to $102.78 \mathrm{~cm}$, the width ranged from 80.52 to $81.59 \mathrm{~cm}$, and the weight ranged from 1.27 to $1.33 \mathrm{~kg}$. The area of the skins was in the range from 82.00 to $83.86 \mathrm{dm}^{2}$, which is less by 8.0 and
$6.14 \mathrm{dm}^{2}$ in comparison with data provided by A.D. Mukhachev [17]. The area of calf skin was $90-120 \mathrm{dm}^{2}$.

TABLE 1. CHARACTERISTICS OF DEER SKIN ACCORDING TO AGE

\begin{tabular}{|l|c|c|c|}
\hline \multicolumn{1}{|c|}{ Indicator } & \multicolumn{1}{|c|}{$\begin{array}{c}\text { OAO State } \\
\text { Farm } \\
\text { Baydaratsky }\end{array}$} & ZAO Nydinskoe & $\begin{array}{c}\text { Municipal } \\
\text { Deer Farm } \\
\text { Yarsalinskoe }\end{array}$ \\
\hline \multicolumn{3}{|c|}{ Young stock (n=29) } \\
\hline $\begin{array}{l}\text { Skin length, } \\
\mathrm{cm}\end{array}$ & $101.82 \pm 6.69$ & $102.01 \pm 4.55$ & $102.78 \pm 5.47$ \\
\hline $\begin{array}{l}\text { Skin width, } \\
\mathrm{cm}\end{array}$ & $80.52 \pm 6.65$ & $81.17 \pm 6.33$ & $81.59 \pm 5.72$ \\
\hline Skin size, dm ${ }^{2}$ & $82.00 \pm 10.93$ & $82.80 \pm 8.72$ & $83.86 \pm 9.56$ \\
\hline $\begin{array}{l}\text { Skin weight, } \\
\mathrm{kg}\end{array}$ & $1.27 \pm 0.72$ & $1.30 \pm 0.82$ & $1.33 \pm 0.77$ \\
\hline $\begin{array}{l}\text { Weight of 1 } \\
\mathrm{dm}{ }^{2} \text { of skin, g }\end{array}$ & $15.47 \pm 7.91$ & $15.68 \pm 8.95$ & $15.83 \pm 8.79$ \\
\hline \multicolumn{4}{|c|}{ Mature deer (n=25) } \\
\hline $\begin{array}{l}\text { Skin length, } \\
\mathrm{cm}\end{array}$ & $134.71 \pm 6.87$ & $134.66 \pm 7.12$ & $134.80 \pm 6.27$ \\
\hline $\begin{array}{l}\text { Skin width, } \\
\mathrm{cm}\end{array}$ & $102.49 \pm 7.07$ & $103.44 \pm 6.55$ & $104.00 \pm 7.61$ \\
\hline Skin size, dm ${ }^{2}$ & $138.08 \pm 15.42$ & $139.31 \pm 15.03$ & $140.20 \pm 15.97$ \\
\hline $\begin{array}{l}\text { Skin weight, } \\
\mathrm{kg}\end{array}$ & $3.20 \pm 0.94$ & $3.34 \pm 0.63$ & $3.37 \pm 0.71$ \\
\hline $\begin{array}{l}\text { Weight of 1 } \\
\mathrm{dm}^{2} \text { of skin, g }\end{array}$ & $23.13 \pm 5.15$ & $23.94 \pm 2.98$ & $24.04 \pm 3.24$ \\
\hline
\end{tabular}

The skin quality of stud bulls and steers, as well as length, width, area, and weight was greater in deer from Municipal Deer Farm Yarsalinskoe and amounted to $134.8 \mathrm{~cm} ; 104.0 \mathrm{~cm}$; $140.2 \mathrm{dm}^{2}, 3.37 \mathrm{~kg}$, respectively. According to D.I. Syrovatskiy, M.P. Neustroev [21], the area of skins of stud bulls and steers is $125-175 \mathrm{dm}^{2}$. The data obtained in the course of this study correspond to the same range.

The deer skins are not very thick, but they are distinguished by high strength and tensile properties.

To the present day, the peoples of the North make clothes and shoes from the deer skin. They also make coverings for mobile homes, make sleeping bags and blankets, and warm the cradles. The skin is used for warming the floor in their dwellings; it is put on sledges for warmth and comfort, the skin is also used to cover goods transported on sleds. Besides, the reindeer fur is used for making hats, fur clothes, as well as durable and beautiful shoes. Felt boots with leather soles and boots made from reindeer skin are in high demand among the population. In addition, the reindeer skin is used for finishing and making souvenirs, as well as for making bags.

However, the skins obtained during the mass slaughter are not really valuable. The skins of young animals, in particular, the skins of calves up to 3 months are in high demand.

Based on the above, one may conclude that the minimum values for all indicators were found in the skins obtained from the State Farm Baydaratsky, and the maximum values were found in the Municipal Deer Farm Yarsalinskoe. This is probably due to the fact that the deer of Nenets breed are larger in size in the Municipal Deer Farm Yarsalinskoe.

Characteristics of the hair of Nenets deer are presented in Table 2. 
TABLE 2. CHARACTERISTICS OF DEER HAIR

\begin{tabular}{|c|c|c|c|c|c|}
\hline \multirow{2}{*}{ Enterprises } & \multirow{2}{*}{ Age } & \multicolumn{2}{|c|}{ Number of hairs, pes } & \multicolumn{2}{|c|}{ Hair length, mm } \\
\hline & & top hair & fur hair & top hair & fur hair \\
\hline \multicolumn{6}{|c|}{ Females } \\
\hline $\begin{array}{l}\text { OAO State } \\
\text { Farm } \\
\text { Baydaratsky }\end{array}$ & \multirow{3}{*}{$\begin{array}{c}0.5 \\
\text { years } \\
\text { old }\end{array}$} & $1252.3 \pm 27.8$ & $631.3 \pm 26.5$ & $31.8 \pm 0.4$ & $24.3 \pm 0.4$ \\
\hline $\begin{array}{c}\text { ZAO } \\
\text { Nydinskoe }\end{array}$ & & $1271.3 \pm 5.9$ & $687.7 \pm 3.6$ & $32.3 \pm 0.5$ & $24.7 \pm 0.2$ \\
\hline $\begin{array}{c}\text { Municipal } \\
\text { Deer Farm } \\
\text { Yarsalinskoe }\end{array}$ & & $1279.7 \pm 5.7$ & $719.7 \pm 3.3^{*}$ & $30.8 \pm 1.3$ & $24.6 \pm 0.4$ \\
\hline $\begin{array}{c}\text { OAO State } \\
\text { Farm } \\
\text { Baydaratsky }\end{array}$ & \multirow{3}{*}{$\begin{array}{c}1.5 \\
\text { years } \\
\text { old }\end{array}$} & $1027.0 \pm 55.2$ & $538.3 \pm 123.6$ & $30.8 \pm 0.6$ & $23.7 \pm 0.9$ \\
\hline $\begin{array}{c}\text { ZAO } \\
\text { Nydinskoe }\end{array}$ & & $1003.3 \pm 14.7$ & $618.0 \pm 39.7$ & $31.0 \pm 0.7$ & $24.1 \pm 0.3$ \\
\hline $\begin{array}{c}\text { Municipal } \\
\text { Deer Farm } \\
\text { Yarsalinskoe }\end{array}$ & & $1019.7 \pm 5.9$ & $685.7 \pm 9.4$ & $32.2 \pm 0.5$ & $24.6 \pm 0.7$ \\
\hline $\begin{array}{l}\text { OAO State } \\
\text { Farm } \\
\text { Baydaratsky }\end{array}$ & \multirow{3}{*}{$\begin{array}{c}3.5 \\
\text { years } \\
\text { old }\end{array}$} & $675.7 \pm 22.1$ & $560.7 \pm 17.7$ & $33.6 \pm 1.0$ & $29.0 \pm 2.3$ \\
\hline $\begin{array}{c}\text { ZAO } \\
\text { Nydinskoe }\end{array}$ & & $787.3 \pm 45.3$ & $674.3 \pm 15.5^{* *}$ & $33.4 \pm 0.5$ & $29.3 \pm 1.1$ \\
\hline $\begin{array}{c}\text { Municipal } \\
\text { Deer Farm } \\
\text { Yarsalinskoe }\end{array}$ & & $778.0 \pm 54.2$ & $687.7 \pm 40.7^{*}$ & $33.5 \pm 0.1$ & $29.1 \pm 1.6$ \\
\hline $\begin{array}{c}\text { OAO State } \\
\text { Farm } \\
\text { Baydaratsky }\end{array}$ & \multirow{3}{*}{$\begin{array}{c}4.5 \\
\text { years } \\
\text { old }\end{array}$} & $598.7 \pm 17.7$ & $468.0 \pm 29.8$ & $34.1 \pm 0.4$ & $24.8 \pm 1.4$ \\
\hline $\begin{array}{c}\text { ZAO } \\
\text { Nydinskoe }\end{array}$ & & $609.0 \pm 16.7$ & $559.3 \pm 9.4^{*}$ & $34.2 \pm 0.5$ & $25.2 \pm 0.6$ \\
\hline $\begin{array}{c}\text { Municipal } \\
\text { Deer Farm } \\
\text { Yarsalinskoe }\end{array}$ & & $634.3 \pm 15.6$ & $590.3 \pm 18.5^{*}$ & $34.6 \pm 0.3$ & $25.5 \pm 0.5$ \\
\hline \multicolumn{6}{|c|}{ Males } \\
\hline $\begin{array}{l}\text { OAO State } \\
\text { Farm } \\
\text { Baydaratsky }\end{array}$ & \multirow{3}{*}{$\begin{array}{c}0.5 \\
\text { years } \\
\text { old }\end{array}$} & $1142.3 \pm 21.5$ & $593.3 \pm 16.1$ & $31.5 \pm 0.2$ & $23.6 \pm 0.5$ \\
\hline $\begin{array}{c}\text { ZAO } \\
\text { Nydinskoe }\end{array}$ & & $1182.7 \pm 16.1$ & $622.7 \pm 16.3$ & $31.5 \pm 0.1$ & $23.9 \pm 0.2$ \\
\hline $\begin{array}{c}\text { Municipal } \\
\text { Deer Farm } \\
\text { Yarsalinskoe }\end{array}$ & & $1211.7 \pm 4.3^{*}$ & $670.0 \pm 9.9^{*}$ & $31.9 \pm 0.3$ & $24.5 \pm 0.3$ \\
\hline $\begin{array}{c}\text { OAO State } \\
\text { Farm } \\
\text { Baydaratsky }\end{array}$ & \multirow{3}{*}{$\begin{array}{c}1.5 \\
\text { years } \\
\text { old }\end{array}$} & $645.7 \pm 29.1$ & $441.3 \pm 65.0$ & $32.0 \pm 0.4$ & $24.9 \pm 0.2$ \\
\hline $\begin{array}{c}\text { ZAO } \\
\text { Nydinskoe }\end{array}$ & & $681.3 \pm 22.0$ & $467.3 \pm 34.0$ & $32.1 \pm 0.3$ & $25.1 \pm 0.1$ \\
\hline $\begin{array}{c}\text { Municipal } \\
\text { Deer Farm } \\
\text { Yarsalinskoe }\end{array}$ & & $685.0 \pm 13.0$ & $511.7 \pm 6.7$ & $32.2 \pm 0.2$ & $25.1 \pm 0.3$ \\
\hline $\begin{array}{l}\text { OAO State } \\
\text { Farm } \\
\text { Baydaratsky }\end{array}$ & \multirow{3}{*}{$\begin{array}{c}3.5 \\
\text { years } \\
\text { old }\end{array}$} & $689.0 \pm 20.0$ & $665.3 \pm 10.0$ & $33.9 \pm 0.3$ & $29.5 \pm 0.2$ \\
\hline $\begin{array}{c}\text { ZAO } \\
\text { Nydinskoe }\end{array}$ & & $724.7 \pm 13.4$ & $713.7 \pm 16.3$ & $34.0 \pm 0.3$ & $30.4 \pm 1.1$ \\
\hline $\begin{array}{c}\text { Municipal } \\
\text { Deer Farm } \\
\text { Yarsalinskoe }\end{array}$ & & $754.7 \pm 12.8^{*}$ & $747.0 \pm 12.1 * *$ & $34.0 \pm 0.3$ & $30.4 \pm 1.1$ \\
\hline $\begin{array}{c}\text { OAO State } \\
\text { Farm } \\
\text { Baydaratsky }\end{array}$ & \multirow{3}{*}{$\begin{array}{c}4.5 \\
\text { years } \\
\text { old }\end{array}$} & $598.0 \pm 17.0$ & $571.3 \pm 22.7$ & $33.7 \pm 0.2$ & $31.9 \pm 0.3$ \\
\hline $\begin{array}{c}\text { ZAO } \\
\text { Nydinskoe }\end{array}$ & & $640.0 \pm 9.3$ & $616.7 \pm 20.1$ & $33.6 \pm 0.2$ & $32.1 \pm 0.4$ \\
\hline $\begin{array}{c}\text { Municipal } \\
\text { Deer Farm } \\
\text { Yarsalinskoe }\end{array}$ & & $665.3 \pm 15.0^{*}$ & $644.3 \pm 14.2$ & $33.7 \pm 0.2$ & $32.4 \pm 0.2$ \\
\hline
\end{tabular}

Note: * $\mathrm{P}>0.95 ; * *$ - $\mathrm{P}>0.99 ; * * *$ - $\mathrm{P}>0.999$ (and so on according the tables).
TABLE 3. STRUCTURE OF HAIR FRACTIONS

\begin{tabular}{|c|c|c|c|}
\hline \multirow{2}{*}{ Enterprises } & \multirow{2}{*}{ Age } & \multicolumn{2}{|c|}{ Hair structure, \% } \\
\hline & & top hair & fur hair \\
\hline \multicolumn{4}{|c|}{ Females } \\
\hline $\begin{array}{l}\text { OAO State Farm } \\
\text { Baydaratsky }\end{array}$ & \multirow{3}{*}{$\begin{array}{l}0.5 \text { years } \\
\text { old }\end{array}$} & 66.5 & 33,5 \\
\hline ZAO Nydinskoe & & 64.9 & 35.1 \\
\hline $\begin{array}{l}\text { Municipal Deer } \\
\text { Farm Yarsalinskoe }\end{array}$ & & 64.0 & 36.0 \\
\hline $\begin{array}{l}\text { OAO State Farm } \\
\text { Baydaratsky }\end{array}$ & \multirow{3}{*}{$\begin{array}{l}1.5 \text { years } \\
\text { old }\end{array}$} & 65.8 & 34.2 \\
\hline ZAO Nydinskoe & & 61.9 & 38.1 \\
\hline $\begin{array}{l}\text { Municipal Deer } \\
\text { Farm Yarsalinskoe }\end{array}$ & & 59.8 & 40.2 \\
\hline $\begin{array}{l}\text { OAO State Farm } \\
\text { Baydaratsky }\end{array}$ & \multirow{3}{*}{$\begin{array}{l}3.5 \text { years } \\
\text { old }\end{array}$} & 54.7 & 45.3 \\
\hline ZAO Nydinskoe & & 53.9 & 46.1 \\
\hline $\begin{array}{l}\text { Municipal Deer } \\
\text { Farm Yarsalinskoe }\end{array}$ & & 53.1 & 46.9 \\
\hline $\begin{array}{l}\text { OAO State Farm } \\
\text { Baydaratsky }\end{array}$ & \multirow{3}{*}{$\begin{array}{l}4.5 \text { years } \\
\text { old }\end{array}$} & 56.1 & 43.9 \\
\hline ZAO Nydinskoe & & 52.1 & 47.9 \\
\hline $\begin{array}{l}\text { Municipal Deer } \\
\text { Farm Yarsalinskoe }\end{array}$ & & 51.8 & 48.2 \\
\hline \multicolumn{4}{|c|}{ Males } \\
\hline $\begin{array}{l}\text { OAO State Farm } \\
\text { Baydaratsky }\end{array}$ & \multirow{3}{*}{$\begin{array}{l}0.5 \text { years } \\
\text { old }\end{array}$} & 65.8 & 34.2 \\
\hline ZAO Nydinskoe & & 65.5 & 34.5 \\
\hline $\begin{array}{l}\text { Municipal Deer } \\
\text { Farm Yarsalinskoe }\end{array}$ & & 64.4 & 35.6 \\
\hline $\begin{array}{l}\text { OAO State Farm } \\
\text { Baydaratsky }\end{array}$ & \multirow{3}{*}{$\begin{array}{l}1.5 \text { years } \\
\text { old }\end{array}$} & 59.5 & 40.5 \\
\hline ZAO Nydinskoe & & 59.3 & 40.7 \\
\hline $\begin{array}{l}\text { Municipal Deer } \\
\text { Farm Yarsalinskoe } \\
\end{array}$ & & 57.2 & 42.8 \\
\hline $\begin{array}{l}\text { OAO State Farm } \\
\text { Baydaratsky }\end{array}$ & \multirow{3}{*}{$\begin{array}{l}3.5 \text { years } \\
\text { old }\end{array}$} & 50.9 & 49.1 \\
\hline ZAO Nydinskoe & & 50.4 & 49.6 \\
\hline $\begin{array}{l}\text { Municipal Deer } \\
\text { Farm Yarsalinskoe }\end{array}$ & & 50.3 & 49.7 \\
\hline $\begin{array}{l}\text { OAO State Farm } \\
\text { Baydaratsky }\end{array}$ & \multirow{3}{*}{$\begin{array}{l}4.5 \text { years } \\
\text { old }\end{array}$} & 51.1 & 48.9 \\
\hline ZAO Nydinskoe & & 50.9 & 49.1 \\
\hline $\begin{array}{l}\text { Municipal Deer } \\
\text { Farm Yarsalinskoe }\end{array}$ & & 50.8 & 49.2 \\
\hline
\end{tabular}

Analyzing the data obtained, it can be concluded that the hair covering is much better developed in young animals. With age there is a gradual decrease in the hair thickness and a slight increase in the hair length.

Young animals have the most dense and relatively short hair. At this age the top hair is very thin and soft and are close in its structure to the down hair. At the age of one and a half years old there is a noticeable decrease in the hair density (from 30 to $40 \%$ ). It should be noted that in females the number of hairs per $1 \mathrm{~cm} 2$ of skin prevails over males; however, in males the top hair is visually thicker, and there is more down hair in the structure (Table 3).

The steers had the thickest top hair (about 250 microns) with a strongly developed and long fur fiber, about 12 microns. Downy fibers tightly intertwine the top hair preventing it from disintegration. The proportion of the down hair stayed within $53 \%$ of the number of all fibers in the hair structure. In steers (6 years of age and older) there was a slight 
difference in the length of top and down hair (within $1 \mathrm{~mm}$ ) in favor of the top hair. The longest hair (top and down hair), overgrowing the main length of the hair, bend at the ends to the main mass, forming an even staple.

In the structure of the hair covering of different age and gender groups, some peculiarities were observed. Compared to males, the females had a slight advantage regarding the top hair. However, the downy fiber characteristics were much better in males. The young stock of the current and previous years had significant difference in the ratio of top and down hair, which is associated with age, and so called hair immaturity. The she-deer of the productive age had this difference within $10 \%$ with the predominance of top hair. On the contrary, the steers and riding bulls had the best development of down hair (within $6 \%$ difference).

Throughout its length, hair was of different colors, i.e. the hair base had a gray tint, the middle part was dark-gray, and the hair end was gray with yellowish tint, which is associated with the exposure to the sun and precipitations.

The coloring of the hair in deer is a variable morphological feature. However, the similarity of deer in a herd by color indicates a more stable heredity of animals. The hair coloring of deer determines the number and distribution of pigments of melanin, guanidine and carotenoid substances. The color of reindeer is determined by the method provided by E.S. Lenartovich [16].

In summer, the body of a deer is covered with short dark hair. By autumn, the wool grows and in winter it becomes lighter in color. Calves tend to have a darker coloration compared to adults.

The color of different parts of a deer's body is not the same in intensity. When determining the color of a deer, the main attention is paid to the color of its body. According to A.D. Mukhachev, the reindeer color varies from dark-brown to white $[17,18]$.

Determination of the color of animals in farms was carried out visually, when running deer through the coral. The color characteristics of the animals are presented in Table 4.

The reindeer color depends on the season of the year. In summer, deer are of darker color than in winter, since after changing the winter hair, the covering hair and the underfur grow first. In autumn, the bright top hair begins to grow, due to which the color of deer becomes lighter. In spring, the deer begins to molt, their hair fades, which allows the deer to reflect excessive amounts of ultraviolet radiation. At the end of summer, when radiation is low, the dark color makes it possible for a deer to receive a sufficient amount of ultraviolet radiation. The light color helps saving the inner heat during the snow period.

As a result of the study, it was revealed that dark-brown and brown colors predominate in animals of Nenets deer bred in the OAO State Farm Baydaratsky, ZAO Nydinskoe, Municipal Deer Farm Yarsalinskoe, which makes up more than half of the livestock. The body of such animals is colored gray-brown, the neck and sides may be light gray, the limbs and the belly are usually dark.
TABLE 4. CHARACTERISTICS OF ANIMALS BY COLOR

\begin{tabular}{|l|c|c|c|c|c|c|c|c|}
\hline \multirow{2}{*}{ Color } & \multicolumn{2}{|c|}{ Total } & \multicolumn{5}{c|}{$\begin{array}{c}\text { OAO State } \\
\text { Farm } \\
\text { Baydaratsky }\end{array}$} & \multicolumn{2}{c|}{$\begin{array}{c}\text { ZAO } \\
\text { Nydinskoe }\end{array}$} & $\begin{array}{c}\text { Municipal Deer } \\
\text { Farm } \\
\text { Yarsalinskoe }\end{array}$ \\
\cline { 2 - 9 } & heads & $\%$ & heads & $\%$ & heads & $\%$ & heads & $\%$ \\
\hline $\begin{array}{l}\text { Dark- } \\
\text { brown }\end{array}$ & 1.290 & 25.4 & 524 & 29.5 & 312 & 20.6 & 454 & 25.5 \\
\hline Brown & 1.745 & 34.4 & 489 & 27.5 & 567 & 37.4 & 689 & 38.7 \\
\hline $\begin{array}{l}\text { Light- } \\
\text { brown }\end{array}$ & 774 & 15.3 & 323 & 18.2 & 284 & 18.7 & 167 & 9.4 \\
\hline $\begin{array}{l}\text { Dark- } \\
\text { gray }\end{array}$ & 349 & 6.9 & 157 & 8.8 & 64 & 4.2 & 128 & 7.2 \\
\hline Gray & 349 & 6,9 & 98 & 5.5 & 118 & 7.8 & 133 & 7.5 \\
\hline $\begin{array}{l}\text { Light- } \\
\text { gray }\end{array}$ & 326 & 6.4 & 112 & 6.3 & 99 & 6.5 & 115 & 6.4 \\
\hline $\begin{array}{l}\text { Black- } \\
\text { and- } \\
\text { white }\end{array}$ & 177 & 3,5 & 59 & 3.3 & 42 & 2.8 & 76 & 4.3 \\
\hline White & 61 & 1.2 & 14 & 0.9 & 29 & 2.0 & 18 & 1.0 \\
\hline Total & 5.071 & 100 & 1.776 & 100 & 1.515 & 100 & 1.780 & 100 \\
\hline
\end{tabular}

Deer colored light-brown are distinguished by a lighter coat color; their limbs and belly are also dark.

Deer colored dark-brown have almost no dark top hair; light-brown deer have this hair type on the forehead, ears, legs and neck, and the gray ones have the top hair all over the body.

In black-and-white deer, the white hair is spread over the body in spots of various sizes and shapes. Such animals are found in herds as single individuals. Black-and-white deer are very beautiful; therefore, herders call them 'nuggets'. The skin of 'nuggets' is used to decorate festive clothing of men and especially women. There are also very few light, gray and white deer. Animals of these colors are considered less strong and enduring compared to deer of other colors (especially brown of different shades). When wolves attack a herd, these deer are the first to suffer. Such deer are mainly kept as 'domestic animals' for children and as riding deer. A great advantage of deer of this color is their beautiful coat color. The skin of these deer is used to make decorative fur products and to tailor women's clothing $[19,20]$.

\section{CONCLUSION}

The analysis of hair characteristics of Nenets deer of different age and sex groups showed its best development in young animals. It was noted that with age there is a gradual decrease in the hair thickness and a slight increase in its length. The females' hair is denser compared to the males' hair; however, in males the top hair is visually thicker, and the structure has more down hair. Traditionally preferred hair color of Nenets deer in the YNAO reindeer herding is darkbrown.

\section{References}

[1] A.S. Sergeevna, S.O Anatolevich., S.G. Nurchallaeva, "Silver in the meat and organs of broiler chickens in case of using colloidal silver as an alternative to antibiotics", et al, Biometals, 2018, https://doi.org/10.1007/s10534-018-0141-3. 
[2] A. G. Koshchaev, I. V. Shchukina, M. P. Semenenko, K. A. Sergeevna, K. V. Vasilevich, Amino Acid Profile of Meat of Specialized Beef Breeds, Research Journal of Pharmaceutical Biological and Chemical Sciences, vol. 7, 2016, pp 670-676

[3] A. A. Nesterenko, A. G. Koshchaev, N. V. Kenijz, D. S. Shhalahov, K. R. Vilts, "Development of device for electromagnetic treatment of raw meat and starter cultures", Research Journal of Pharmaceutical Biological and Chemical Sciences, vol. 8, 2017, pp. 1080-1085.

[4] A. A. Nesterenko, A. G. Koshchaev, N. V Kenijz., D. S. Shhalahov, K. R. Vilts, "Effect of low frequency electromagnetic treatment on raw meat", Research Journal of Pharmaceutical Biological and Chemical Sciences, vol. 8, 2017, pp. 1071-1079.

[5] G. A. Plutakhin, A. G. Koshchaev, I. M. Donnik, "Quality Assessment of Chicken Meat by Analysis-Of-Variance Method", Research Journal of Pharmaceutical Biological and Chemical Sciences, vol. 7, 2016, pp. 2293-2299.

[6] M.A. Chasovshchikov, O.M. Sheveleva, M.A. Svjazhenina, N.I. Tatarkina, A.B. Satkeeva, A.A.Bakharev, E.A. Ponomareva, A.G. Koshchaev, "Relationship between the genetic variants of kappa-casein and prolactin and the productive-biological characteristics of cows of the black-motley breed", Journal of Pharmaceutical Sciences and Research, vol. 9, No. 7, July 2017, pp. 1038-1044.

[7] A.V. Garkovenko, V. V. Radchenko, E. V. Ilnitskaya, A. G. Koshchaev, I. V. Shchukina, A. A. Bakharev, S. F. Sukhanova, "Polymorphism of cattle microsatellite complexes" Journal of Pharmaceutical Sciences and Research, Vol. 10(6), 2018, pp. 1545-1551.

[8] L.A. Glazunova, Yu.V. Glazunov, A.A. Ergashev, "Ecologicalepizootical situation on telasiosis among large cattle in northern Ural region", Research Journal of Pharmaceutical, Biological and Chemical Sciences, 2018, vol.. 9, No. 4, pp. 1687-1693.

[9] D.I. Eremin, D.V. Eremina, "Influence of transport infrastructure on water permeability of soil of Western Sibiria", IOP Conference Series: Earth and Environmental Science, vol.90, 2017, No. 1, doi.org/10.1088/1755-1315/90/1/012111.
[10] A.A. Bakharev, "Peculiarities of hair covering of beef cattle breeds in the conditions of Trans-Urals", Agrarian Bulletin of Urals, 2011, vol. 92, No. $12-2$, pp. 8-9.

[11] A.A. Bakharev, "Peculiarities of hair covering of beef cattle breeds in the conditions of Trans-Urals", Agrarian Bulletin of Urals, 2011, vol. 92, No. $12-2$, pp. $8-9$.

[12] A.A. Baharev, O.M. Sheveleva, "Peculiarities of hair covering of firstcalf cows of the Limousin breed in the process of their adjustment under the conditions of Northern Trans-Urals", Agrarian Bulletin of Urals, 2016, vol. 154, No. 12, pp. 19-23.

[13] A.Y. Sokolov, A.V. Kushnir, "Bioenergy reindeer", Novosibirsk: Science, 1986, p. 97.

[14] E.E. Syroechkovsky, M. Reindeer: Agropromizdat, 1986, p. 256.

[15] L.P. Prahov, G.A. Chernov, "Guidelines for the study of adjustment abilities of cattle meat breeds", Orenburg, 1977, p. 24.

[16] O.M Sheveleva., A.A. Bakharev, "A device for sampling hair", Patent RUS. 139419. 07.23.2013, Publ. 04/20/2014, No. 11

[17] E.S. Lenartovich, "On the question of the color of reindeer",/ Northern reindeer breeding, 1936,. vol. 8. pp. 61-68.

[18] A.D. Muhachev, "Reindeer breeding", Moscow: Agropromizdat, 1990 p. 272.

[19] A.D. Muhachev, "Variability in the color of reindeer in central Siberia", Breeding of reindeer: Scientific and technical bulletin, Novosibirsk: RAAS. Sib. Separate NIISH Far North, 1994, vol. 1, pp. 27-35.

[20] A.A. Yuzhakov, "Personal deer as preservation of reindeer herding", Agri-food policy of Russia, 2017, vol. 63, No.3, pp. 65-69.

[21] Arctic Council 2000-2002, "Sustainable reindeer husbandry",.Report Published by University of Tromso, 2002, p. 157.

[22] D.I. Syrovatsky, M.P. Neustroev, "Current state and prospects for the development of northern reindeer husbandry in Russia Recommendations", Moscow: State Scientific Institution Rosinformagrotekh, 2007, p. 132 . 